\title{
IAMJ
}

INTERNATIONAL

AYURVEDIC

MEDICAL JOURNAL

Research Article

ISSN: 2320-5091

Impact Factor: 6.719

\section{TO EVALUATE THE EFFECT OF UPANAHA SWEDA IN JANUSANDHIGATA VATA WITH VACHADI AND KOLADI YOGAS A COMPARATIVE CLINICAL STUDY}

\author{
Desai Sucheta $^{1}$, Desai Ananta ${ }^{2}$, Borannavar Shaila ${ }^{3}$ \\ ${ }^{1}$ P.G. Scholar, ${ }^{2}$ HOD \& Professor, ${ }^{3}$ Guide \& Associate Professor, \\ Dept of Panchakarma, Govt. Ayurveda Medical College, Bengaluru, Karnataka, India
}

Corresponding Author: suchetateggi@gmail.com

\section{https://doi.org/10.46607/iamj1209082021}

(Published Online: August 2021)

Open Access

(C) International Ayurvedic Medical Journal, India 2021

Article Received: 22/07//2021 - Peer Reviewed: 02/08/2021 - Accepted for Publication: 03/08/2021

\section{Check for updates}

\section{ABSTRACT}

The present scenario of lifestyle is prone to cause many lives deteriorating conditions. Sandhigatavata is one among the Vatavyadhi and the commonest articular disorder affecting the middle-aged, obese, and elderly population. The advancement in working pattern, lifestyle \& age-factor, all together have become a prime cause for aggravation of Vata, which accelerates Dhatukshaya (depletion of tissues). Sandhigatavata can be correlated with osteoarthritis (OA) which is one such chronic, degenerative, inflammatory disease that has a great impact on the quality of the life of an individual. OA poses a huge hindrance in the day-to-day activities of the sufferer like walking, dressing, bathing etc. As per Ayurveda, it is caused due to localized accumulation of aggravated Vata in joints, which leads to Shula, Sotha, Vatapoornadritisparsha and functional disability of affected Sandhis. If not treated in time, the disease makes man disable. According to epidemiology the prevalence of osteoarthritis in India is 22-39\%. Different treatment modalities like Snehana, Swedana, Lepa, Bandhana, Agni Karma and Raktamokshana are emphasized in Ayurveda to provide better relief from the pain and swelling and restore mobility; for the management of these symptoms, Swedana is the most convenient \& best procedure. So, the present study was aimed to assess clinically the effect of Upanaha Swedas in the management of Janusandhigatavata. Objectives: To evaluate and compare the efficacy of Vachadi Upanaha Sweda and Koladi Upanaha Sweda in the management of Janusandhigatavata.

Materials and Methods: It was a randomized comparative clinical study; total 40 patients were divided into 2 groups as 20 in each. In Group A, patients were treated with only Vachadi Upanaha Sweda and other group patients were treated with Koladi Upanaha Sweda. Results: Statistical analysis revealed that both the interventions were 
effective in reducing all the signs and symptoms of Janusandhigatavata, however in parameters Shotha, tenderness and walking distance, Koladi Upanaha Sweda showed better response than Vachadi Upanaha Sweda. Conclusion: There is a significant effect of Koladi Upanaha Sweda over Vachadi Upanaha Sweda in Janusandhigatavata both clinically and statistically.

Keywords: Janusandhigatavata, knee osteoarthritis, Koladi Upanaha, Vachadi Upanaha, Swedana.

\section{INTRODUCTION}

Panchakarma is the specialized branch of Ayurveda which has got the importance in its own special way in preventive as well as curative aspects of the diseases. Even though Panchakarma includes the mainstream procedures like Vamana, Virechana, Basti, Nasya and Raktamokshana, the Upakarmas like Snehana and Swedana has also got its impact very strongly in treating the diseases. As said in treatises Swedana is considered one of the important aspects in Shadvidha Upakrama. As Pradhana Karma numerous varieties of Swedana can be adopted according to the disease condition. Among them Upanaha Sweda is the variety mentioned by our Acharyas which is mainly indicated in Vataja disorders. Sandhigatavata ${ }^{l}$ or Osteo-arthritis is a type of Vatavyadhi which mainly occurs in Vriddhavastha due to Dhatukshaya and is the commonest form of articular disorder. It limits everyday activities such as walking, dressing, bathing etc. thus making patient disabled/handicapped. Vatavyadhi, affecting Marmasthisandhi ${ }^{[2]}$ and its occurrence in old age makes it Kastasadhya for the Chikitsa. Till date no medicine is available which prevents, reverses, or blocks the growth of this disease. Acharya Charaka defined it as a disease with the symptoms of Shoola, Shotha, which is palpable as an air-filled bag (Vatapoornadritisparsha) with pain on flexion \& extension of affected joint. ${ }^{[3]}$ Sandhivata is accepted by Chakrapani as Gulphavata or Sandhigatavata. In Allopathic science it can be correlated with osteoarthritis. It's a Degenerative joint disorder that occurs when flexible tissue at the end of a bone wears down. ${ }^{[4]}$ According to Epidemiology the prevalence of OA in India is $22-39 \%$. A common misconception is that OA is solely due to wear and tear, since OA is typically a disease of persons in the fifth decade and beyond, but OA is not the result of a bland degenerative process; rather, OA involves both degenerative and regenerative processes. Radiographic evidence of this disease is present in most persons by 65yrs of age \& in about $80 \%$ of persons more than $75 \mathrm{yr}$ of age. ${ }^{[5]}$

The major risk factors associated with Knee joint are Age, female sex, obesity, occupational knee bending \& making it an important cause of disability. There is no satisfactory, comprehensive \& time bound treatment schedule for its management at present. A number of analgesics and anti-inflammatory drugs are available for its betterment. However, a permanent relief is not provided by any of these and the same is still under research works. Even the surgical treatment does not provide complete relief. ${ }^{[6]}$

Acharyas have given great importance to Swedana Karma in the management of Janusandhigatavata. Different modalities of treatment have been explained in the Shastras. Sushruta Samhita and Chakradatta have given the following methods of treatment for Sandhigatavata - Snehana, Upanaha, Agnikarma, Bandhana. ${ }^{[7,8]}$ Among different types of Vatopakramas, Bahyasnehana and Swedana Karma are said to be the best Sthanika Chikitsa to pacify Vata in localized area. Here the use of Upanaha as Swedana Karma may prove more effective for quick relief from symptoms and early mobility of the patients, which is the main purpose of this study. So, here Upanaha with Charakokta Vatahara Koladi Choorna ${ }^{[9]}$ and Vagbhatokta Vachadi Choorna ${ }^{[10]}$ have been selected for comparative study, which may prove to be efficacious in reducing the pain, swelling, stiffness and restore the normal movements of Knee joint.

\section{OBJECTIVES OF THE STUDY:}

1. To evaluate the efficacy of Vachadi Upanaha Sweda in Janusandhigatavata. 
2. To evaluate the efficacy of Koladi Upanaha Sweda in Janusandhigatavata.

3. To compare the efficacy of Vachadi Upanaha Sweda and Koladi Upnaha Sweda in Janusandhigatavata.

\section{MATERIALS AND METHODS:}

Source of Data: The patients who attended OA camp conducted by the Panchakarma OPD at SJIIM Hospital \& GAMC Bengaluru, with complaints of Knee joint pain and swelling were screened. Out of these, 40 patients of Janusandhigatavata, who fulfilled the below mentioned inclusion criteria were selected for the study.

\section{Selection Criteria:}

\section{Diagnostic criteria:}

The diagnosis was mainly based on these clinical features:

1. Sandhi shoola 2. Sandhi shotha 3. Sandhi atopa 4. Prasaranaakunchanayovedana 5. Tenderness in knee joint
The patients were selected based on the Inclusion and Exclusion criteria.

\section{Inclusion Criteria:}

1. Patients fulfilling the diagnostic criteria of $\mathrm{Ja}$ nusandhigatavata.

2. Patients between age group of 40-70 years.

3. Patients fit for Sthanika Swedana Karma.

\section{Exclusion Criteria:}

1. Patients suffering from any inflammatory arthritis with diseases such as Gouty Arthritis, Rheumatoid Arthritis, fractures.

2. Patients with skin diseases and open lesions on Knee joints.

STUDY DESIGN: The study design set for the present study was a "randomized comparative clinical study". A minimum of 40 patients, fulfilling the inclusion criteria of Janusandhigatavata were selected for the study irrespective of sex, religion, occupation and economic status and they were randomly distributed into 2 groups of 20 patients each.

Table 1: Showing Intervention:

\begin{tabular}{|l|l|l|}
\hline & GROUP A & GROUP B \\
\hline Poorva Karma & Sthanika Abhyanga with Tila Taila & Sthanika Abhyanga with Tila Taila. \\
\hline Pradhana Karma & $\begin{array}{l}\text { Upanaha Sweda with Vachadi Yoga for 15 days } \\
\text { Paschat Karma }\end{array}$ & $\begin{array}{l}\text { Upanaha was retained for 12 hours and after that it was removed, and the part was cleaned with warm } \\
\text { water. }\end{array}$ \\
\hline
\end{tabular}

Follow up on: $15^{\text {th }}$ Day, Study duration: 15 Days

COLLECTION OF DRUGS: Choorna Yogas were collected from Amruta Kesari Ayurveda Pharmacy, Mamulpet Bengaluru.

Modification: Here in this study Amisha was replaced by Masha and Kinwa was replaced by vinegar according to the availability. Vinegar was used as vehicle for mixing powder to make the thick paste of Upanaha Sweda as per requirement.

Table 2: Showing Ingredients of Vachadi Upanaha and Koladi Upanaha Sweda

Group(A): Vachadi Upanaha
Choornas of Vacha, Shatavaha, Devadaru, Rasna, Eranda,
Masha and Yava are taken in equal quantity.
Saindhava lavana 10 gms, Tilataila $20 \mathrm{ml}$, Vinegar- Q.S

Poorva Karma: Collection of essential materials required for Upanaha Sweda, Preparation of the medicine, Preparation of the patient. Before commencement of the treatment an informed consent

\section{Group(B): Koladi Upanaha}

Choornas of Kola, Kulattha, Suradaru, Rasna, Masha, Atasi, Tila, Eranda, Kushta, Vacha, Shatapushpa and Yava are taken in equal quantity. Saindhavalavana $10 \mathrm{gms}$, Tilataila $20 \mathrm{ml}$, Vinegar -Q.S

was taken from the patients, and the patients were evaluated for both Subjective and Objective parameters and grading noted. 


\section{PROCEDURE OF UPANAHA SWEDA:}

Table 3: Materials required for the study:

\begin{tabular}{|l|l|l|}
\hline Sl.No & Name of the Material & Quantity \\
\hline 1 & Upanaha Choorna Yogas - Vachadi (Group A) and Koladi (Group B) & $50-100 \mathrm{gms}$ \\
\hline 2 & Tila Taila & $20 \mathrm{ml}$ \\
\hline 3 & Saindhava Lavana & $10 \mathrm{gms}$ \\
\hline 4 & Vinegar & QS \\
\hline 5 & Saucepan & 1 \\
\hline 6 & Spatula & 1 \\
\hline 7 & Eranda Patra & QS \\
\hline 8 & Bandage cloth & 2 \\
\hline 9 & Goniometer & 1 \\
\hline 10 & Gas stove & 1 \\
\hline 11 & Stopwatch & 1 \\
\hline 12 & Small steel bowls & 2 \\
\hline 13 & Water bath to heat & 1 \\
\hline 14 & Small towel & $2-4$ \\
\hline
\end{tabular}

Preparation of the medicine: Powder of each drug was taken according to the required quantity and then a paste of these powdered drugs was prepared by adding Saindhava Lavana, Tila Taila and Vinegar. This paste was taken in a small bowl and warmed gently by placing the bowl in a water bath. Tila Taila was taken separately in another bowl, luke warmed and kept ready for Abhyanga.

Preparation of the patient: The patient was asked to sit comfortably on a chair, exposing the knee joint to be tied with Upanaha Dravya. The affected knee joint was cleaned with a piece of cotton dipped in warm water and then the area was wiped dry with a towel. Sthanika Abhyanga with Sukhoshna Tila Taila was done.

Pradhana Karma: The prepared paste was applied i.e approximately about 2-3 mm thickness and spread uniformly on the affected knee joint. Eranda Patra were placed over the paste to cover the area properly. After this the knee was bandaged which was not too tight nor too loose. The procedure was done in the evening and the Upanaha was retained for a period of 12 hours.

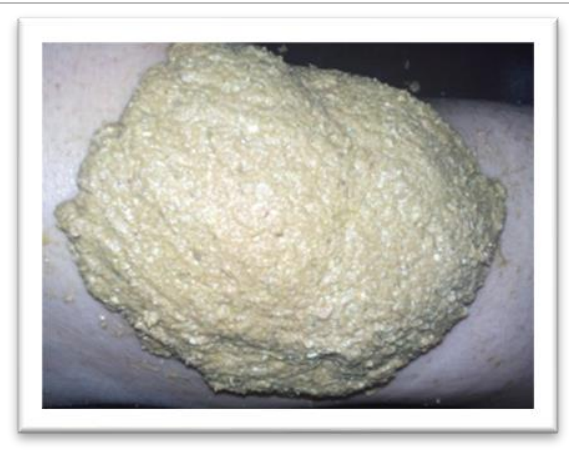

Figure 01: Showing application of Upanaha paste over knee joint
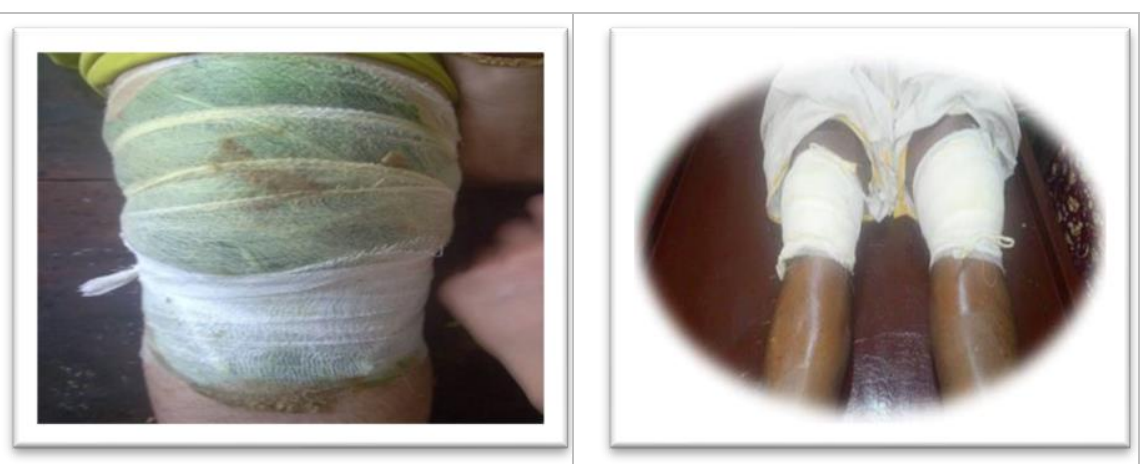

Figure 2: Showing Bandhana of Upanaha
Figure 3: Showing Bandhana of upanaha to $\mathrm{B} / \mathrm{L}$ knee joints
Paschat Karma - The next morning, the bandage along with the paste was removed and the knee joint was washed with lukewarm water and patted dry. The procedure was done for 14 consecutive days in both the groups. Follow up - The patient was advised to report 
on the $15^{\text {th }}$ day for follow up counting from the day the treatment schedule started.

ASSESSMENT CRITERIA: Subjective parameters and objective parameters were used to assess the clinical response in both the groups. The patients were assessed on $1^{\text {st }}$ day (before starting the treatment) and $15^{\text {th }}$ day (after completion of treatment). Subjective Parameters: Pain, Tenderness, Swelling. Objective Parameters: Crepitus, Range of movements (Goniometric examination), Time taken to walk 21 meters distance on even ground.

OBSERVATIONS: A total number of 80 patients were screened for the study, out of which 50 patients met the inclusion criteria. A total number of 50 patients were registered for the present study. 25 patients were registered in group A, 5 patients dropped out in the middle, while 25 patients were registered in Group B, and 5 patients dropped out in the middle. The data of 10 patients who dropped out of the study have not been included here.

\section{Statistical Interpretation:}

Based on unpaired t test, the following observations were recorded.

After treatment - On comparing the results between Group A and Group B, the difference between the two groups was statistically significant w.s.r. to Shotha and time taken to cover 21 metre distance whereas the difference between the two groups was not significant w.s.r. to the rest of the parameters.

Table 4: Showing Overall Effect of Treatments in the study:

\begin{tabular}{|l|l|l|l|l|l|l|}
\hline Characteristics & \multicolumn{3}{l|}{ GROUP-A } & \multicolumn{2}{l|}{ GROUP-B } \\
\hline Signs and Symptoms & Mean score & \% of relief & \multicolumn{2}{l|}{ Mean score } & \% of relief \\
\cline { 2 - 8 } & BT & AT & BT-AT & BT & AT & BT-AB \\
\hline Pain (Janu Shula) & 2.20 & 1.25 & 43.63 & 2.60 & 1.15 & 55.76 \\
\hline Swelling (Janu Shotha) & 2.40 & 1.10 & 54.16 & 2.15 & 0.50 & 76.74 \\
\hline Tenderness & 1.90 & 1.05 & 44.73 & 2.35 & 1.20 & 48.93 \\
\hline Crepitus & 1.05 & 1 & 5 & 1.20 & 1 & 16.66 \\
\hline Range of movement & 1.42 & 0.84 & 45.84 & 1.84 & 1 & 45.65 \\
\hline Walking time to cover 21 mts of distance (sec) & 18.60 & 15.65 & 15.86 & 19.25 & 15.20 & 21.03 \\
\hline
\end{tabular}

The age limit of the subjects in the study was 40 to 70 years. The incidence was highest in the age group $60-69$ years $(55 \%)$, females $(72.5 \%)$, married $(100 \%)$, middle class $(52.5 \%)$, post menopausal period in women $(83 \%)$, Vatapittaja Prakriti (37.5\%), bilateral knee joints (60\%) and chronicity of disease more than 2 years (37.5\%). All 40 patients (100\%) had Sandhi Shoola and Savedana Prasarana Akunchana Pravritti, 34 patients (85\%) had Sandhi Atopa, 31 patients (77.5\%) had Sandhi Shotha, and 24 patients (60\%) had Sandhi Graha.

Table 5: Showing Overall percentage improvement in Clinical Parameters

\begin{tabular}{|l|l|l|l|l|l|l|}
\hline Remarks & Group A & Group B & Total \\
\hline Marked Relief & At & 02 & At & $\%$ & At & $\%$ \\
\hline Moderate Relief & 06 & 10 & 10 & 50 & 12 & 30 \\
\hline Mild Relief & 12 & 30 & 08 & 40 & 14 & 35 \\
\hline No Relief B & 00 & 60 & 02 & 10 & 14 & 35 \\
\hline
\end{tabular}

\section{DISCUSSION}

Irrespective of the stages of Sandhigatavata the constant clinical symptom will be pain and this pain deprives the access for movement in the individuals whereas the same leads to severe pain when attempted to. Along with this the pain will get worse when there is an association of effusion. Hence in order to deal with the primary complaints like pain and effusion Upanaha Sweda is an apt choice in sandhigatavata which gives instant relief from pain as well as effusion in the patients. In the present study, Sagni and Snigdha type of Upanaha Sweda is used. Initially, Sthanika Abhyanga is done with Tila Taila on the affected Knee 
joint. Snehana, whether used externally or internally is said to pacify Prakupita Vata. Here, Tila Taila is used for Abhyanga as well as for preparing the paste for Upanaha helps in alleviating the aggravated Vata. Among the Chaturvidha Sneha, Acharya Charaka has mentioned that Taila is predominantly Vataghna ${ }^{[1]}$. As seen earlier, Tila Taila is best Vatahara because of its properties like Madhura, Tikta, Kashaya Rasa, Guru, Snigdha Guna and Ushna Veerya. So, use of Tila Taila helps in doing the Samprapti Vighatana (reduces Srotoriktata) to some extent. The Snigdha Guna of Tila Taila helps in reducing Rookshata caused due to Vata Prakopa and increases Snehadi Gunas in the Knee joint. This helps significantly in restoring the joint mobility. Also, Taila serves as a lipoidal medium to carry the potency of the drugs (Vachadi and Koladi) by penetrating the epidermis and exerts immediate analgesic and anti-inflammatory effect. Sneha also prevents Upanaha from drying up and causing skin irritation. So, Upanaha can be retained for a longer duration compared to other Lepas. Saindhava Lavana, because of its Sookshma Guna helps the Veerya of the drugs to penetrate into Sookshma Srotas and deeper tissues and pacify the Doshas. Use of Vinegar helps to permeate the active principles from one medium to another. Acharya Sushruta explains the mode of action of Dravyas as follows- The Veerya of Dravyas applied externally on the skin is absorbed by the Tiryak Dhamanis which are attached to the Romakoopas. Through these Romakoopas, the Veerya of the Dravyas enter into the body after undergoing absorption (Paka) through Bhrajaka Pitta present in the skin thus pacifying the Doshas. Warming the paste before application and Ushna Veerya of the Dravyas used in Upanaha help in relaxation of the smooth muscles and local vasodilatation. This increases the blood circulation in the area facilitating supply of oxygen and nutritive materials to the tissues and removal of waste products. Also, the sweat glands of the skin are stimulated which results in increased excretion of liquefied vitiated Doshas from the body leading to Srotoshodhana. Thus, Vatahara Chikitsa in the form of Snehana and Swedana helps in relieving the symptoms. In addition, it hinders the progression of degenerative changes of the Knee joint.

\section{PROBABLE MODE OF ACTION OF UPANAHA SWEDA:}

In general, Swedana therapy is mainly responsible for these activities in body

- Increased metabolic activity

- Increased blood flow

- Stimulation of neural receptors in the skin or tissues

The extent of these activities depends on various factors like

a. The size of the area heated

b. The depths of absorption

c. The duration of heating

d. The intensity of heat

e. The method of application

Due to local rise of temperature, metabolic wastes are removed through increased blood circulation and sweat. The secretion of sweat is under nervous control, especially autonomous. Thus, sudation (Swedana) can bring about changes indirectly on the autonomic nervous system and the heat may reduce pain by acting over nerve stimuli. The application of heat over joint promotes local circulation and metabolic activities and opens the pores of the skin to permit the transfer of medicaments and nutrients towards the affected site. On this basis, it can be assumed that the oil used in Upanaha served as a lipoidal medium for penetration of the drug molecules and exerts an immediate anti-inflammatory effect. Moreover, heat applied with Upanaha increases the local circulation and thus enhances the rate of drug absorption.

\section{CONCLUSION}

Janusandhigatavata is a Vatavyadhi which is one among Ashta Maharoga. Sleshakakapha Kshaya and Vataprakopa due to Vataprakopaka Ahara Vihara, Dhatukshaya, Sthoulya and Vardhakyaavastha have got a major role to play in the manifestation of $\mathrm{Ja}$ nusandhigatavata. By comparing the overall response for the treatment, it can be concluded that Vachadi and Koladi Yogas, both proved to give good results in Sandhigatavata. Koladi Upanaha Sweda proved to be more effective than Kushtadi Upanaha Sweda. When analysed statistically, both the groups showed similar 
effects in reducing all the signs and symptoms of $\mathrm{Ja}$ nusandhigatavata. However, in parameters like Shotha and time taken to walk and cover 21 meters distance Group B patients showed better response than Group A patients. Thus, it can be concluded on the basis of results as well as overall response for the treatment that Koladi Upanaha Sweda is more effective over Vachadi Upanaha Sweda in the management of Janusandhigatavata both clinically and statistically.

\section{REFERENCES}

1. Agnivesha: Charaka Samhitha with Ayurveda Dipika Commentary, Acharya Jadavji Trikamji, Choukambha publication, Varanasi, Chikitsha Sthana, 2000;28.

2. Textbook of Biochemistry, Dinesh Puri, B I Churchill living stone PVT Ltd, New Delhi, 2002; 849.

3. Tripathi Brahmanand, editor Charakasamhita With hindi translation 37 vol 28, Chaukhamba Varanasi, p940.

4. Keuttner KE, Goldberg VM. Introduction. Keuttner KE, Goldberg VM, editors. Osteoarthritis disorders. Rosemont IL: American Academy of Orthopaedic Surgeons, 1995.21-5.

5. Sharma M K, Swami HM, Bhatia V, Verma A, A Epidemological study of co-relates of Osteo- Arthritis in geriatric population.

6. Textbook of Davidson's principles and practice, Editors Stuart H Raiston, Ian D Penman, Mark WJ

Strachan, Richard P Hobson, $23^{\text {rd }}$ edition, Elsewhere Ltd 2018;1010

7. Sushruta, The Sushruta Samhita, with the Nibandha Sangraha Commentary of Shri Dalhanacharya, edited by Y.T.Acharya, Nirnaya Sagar Press, Bombay, 1915, Chikitsa Sthana 4/8, Page - 333.

8. Sri Chakrapanidatta, Chakradatta with the Bhavarthasandipini Hindi Commentary by Sri Jagadishvaraprasad Tripathi, edited by Bhishagratna Pt. Brahmashankar Mishra, Choukambha Press, Varanasi, 2012, Vatavyadhi Chikitsa Adhikara, Shloka no. 9, Page 183.

9. Agnivesha, The Charaka Samhita, revised by Charaka and Dridhabala with Ayurveda Dipika Commentary of Chakrapanidatta, edited by Y.T.Acharya, Nirnaya Sagar Press, Bombay, $3^{\text {rd }}$ edition, 1941, Sutra Sthana 3/18, Page -28 .

10. Vagbhata. Ashtanga Hridaya - with the commentaries of Sarvanga Sundara of Arunadatta and Ayurveda
Rasayana of Hemadri, Edited by Bhishagacharyaharishastry Paradakara Vaidya, $9^{\text {th }}$ edition. Varanasi: Chaukhamba Orientalia 2005, Sutrasthana 17/2,3.

11. Agnivesha, The Charaka Samhita, revised by Charaka and Dridhabala with Ayurveda Dipika Commentary of Chakrapanidatta, edited by Y.T.Acharya, Nirnaya Sagar Press, Bombay, $3^{\text {rd }}$ edition, 1941, Sutra Sthana 13/15, Page -82 .

\section{Source of Support: Nil \\ Conflict of Interest: None Declared}

How to cite this URL: Desai Sucheta et al: To Evaluate The Effect Of Upanaha Sweda In Janusandhigata Vata With Vachadi And Koladi Yogas A Comparative Clinical Study. International Ayurvedic Medical Journal \{online\} 2021 \{cited August 2021\} Available from: http://www.iamj.in/posts/images/upload/1675_1682.pdf 